\title{
Impaired carotid body hypoxic sensing in mice deficient in olfactory receptor 78
}

\author{
Ying-Jie Peng, Anna Gridina, Jayasri Nanduri, Aaron P. Fox and Nanduri R. Prabhakar\$ \\ Institute for Integrative Physiology and Center for Systems Biology of $\mathrm{O}_{2}$ Sensing, University of \\ Chicago, Chicago, Illinois, 60637
}

Running Title: Olfactory receptor 78 and carotid body hypoxic sensing

\$ Address for Correspondence:

Nanduri R. Prabhakar

Institute for Integrative Physiology

The Center for Systems Biology of O2 Sensing

MC 5068

5841 South Maryland Avenue

Chicago, IL 60637

USA

Tel: 773-834-5480

Fax: 77-834-5252

E-mail: nanduri@uchicago.edu 


\section{ABSTRACT}

Carotid bodies are the sensory organs for detecting hypoxemia (decreased arterial blood oxygen levels) and ensuing chemo reflex is a major regulator of breathing and blood pressure. Chang et al (2015) proposed that olfactory receptor 78 (Olfr78) plays a major role in hypoxic sensing by the carotid body. However, such a possibility was questioned by a subsequent study ((TorresTorrelo et al. 2018). The discrepancy between the two reports prompted the present study to reexamine the role of Olfr78 in hypoxic sensing by the carotid body (CB). Studies were performed on age and gender matched Olfr78 knock out mice generated on BL6 and JAX backgrounds and corresponding wild type mice. Breathing was monitored by plethysmography in un-sedated and efferent phrenic nerve activity in anesthetized mice. Carotid body sensory nerve activity was determined ex vivo and $\left[\mathrm{Ca}^{2+}\right]_{\mathrm{i}}$ responses were monitored in isolated glomus cells, the primary $\mathrm{O}_{2}$ sensing cells of the carotid body. Olfr78 null mice on both BL6 and JAX backgrounds exhibited attenuated hypoxic ventilatory response, whereas breathing responses to $\mathrm{CO}_{2}$ were unaffected. The magnitude of hyperoxia-induced depression of breathing (Dejour's test), which is an indirect measure of carotid body hypoxic sensing, was markedly reduced in Olfr78 mutant mice on both background strains. Furthermore, carotid body sensory nerve and glomus cell $\left[\mathrm{Ca}^{2+}\right]_{\mathrm{i}}$ responses to hypoxia were attenuated in BL6 and JAX Olfr78 null mice. These results suggest that Olfr78 plays an important role in hypoxic sensing by the carotid body.

Key Words: G-protein coupled receptors, oxygen sensing, sensory nerve activity, hypoxic ventilator response, carotid body chemo reflex. 


\section{INTRODUCTION}

Carotid bodies (CB) are the sensory organs for detecting decreased arterial blood $\mathrm{O}_{2}$ levels. Hypoxemia increases the $\mathrm{CB}$ sensory nerve activity, and triggers reflex stimulation of breathing and blood pressure to ensure optimal oxygen delivery to tissues (Kumar and Prabhakar 2012). The CB is comprised of two major cell types; glomus or type I cells, which are of neuronal lineage, and sustantecular or type II cells, resembling glial cells of the nervous system. Glomus cells which are in synaptic contact with the afferent nerve ending are considered the primary site of transduction of the hypoxic stimulus (Kumar and Prabhakar 2012). There is considerable debate regarding the sensory transduction in glomus cells (Prabhakar, Peng and Nanduri 2018, Kumar and Prabhakar 2012, Rakoczy and Wyatt 2017).

Olfactory receptors (OR) are G-protein coupled receptors for detecting smell sensation (Schild and Restrepo 1998). Although ORs are originally described in olfactory neurons, emerging evidence suggest that some ORs are also expressed in other tissues (Maßberg and Hatt 2018). Chang et al reported high abundance of Olfr 78 (also known as MOL2.3 and MOR 18-2) gene expression in glomus cells of the mouse carotid body (Chang et al. 2015), a finding that was subsequently confirmed using single cell mRNA analysis in neonatal mice (Zhou et al. 2016). Olfr78 knockout mice exhibit blunted CB sensory nerve excitation, $\left[\mathrm{Ca}^{2+}\right]_{\mathrm{i}}$ elevation of glomus cells by hypoxia and these effects were associated with reduced hypoxic ventilatory response (HVR), which is a hallmark of the CB chemo reflex (Chang et al. 2015). However, a subsequent study reported that HVR, $\left[\mathrm{Ca}^{2+}\right]_{\mathrm{i}}$ and neurotransmitter secretory response of glomus cells to hypoxia were unaffected in Olfr78 knockout mice, thereby questioning the role of Olfr78 signaling in the carotid body hypoxic sensing (Torres-Torrelo et al. 2018). The discrepancy between the studies by Chang et al (2015) and Torres-Torrelo et al (2018) prompted us to reexamine the role of Olfr78 signaling in the CB response to hypoxia. Our results showed that 
HVR monitored either in conscious or anesthetized mice were reduced in Olfr78 knockout mice.

The attenuated HVR was associated with impaired CB sensory nerve excitation in response to graded hypoxia as well as hypoxia-evoked $\left[\mathrm{Ca}^{2+}\right]_{\mathrm{i}}$ elevation in glomus cells. Our results suggest that Olfr78 is an important component of the CB response to hypoxia. 


\section{METHODS}

\section{Preparation of Animals}

Experimental protocols were approved by the Institutional Animal Care and Use Committee of the University of Chicago. Experiments were performed on age-matched adult wild-type (WT) and Olfr78 null mice on C57BL/6 background (BL6, gift from Dr. J. Pluznick, Johns Hopkins University) and on 129P2/OlaHsd background (JAX, gift from Dr. A. Chang, The University of California, San Francisco, UCSF).

\section{Measurements of breathing}

Whole body plethysmography- Ventilation was monitored by whole-body plethysmograph (Buxco, DSI, St. Paul, $\mathrm{MN}$ ), and $\mathrm{O}_{2}$ consumption and $\mathrm{CO}_{2}$ production were determined by the open-circuit method in un-sedated mice as described (Peng et al. 2006). Ventilation was recorded while the mice breathed $21 \%$ or $12 \% \mathrm{O}_{2}$-balanced $\mathrm{N}_{2}$. Each gas challenge was given for 5 min. $\mathrm{O}_{2}$ consumption and $\mathrm{CO}_{2}$ production were measured at the end of each 5-min challenge. For determining ventilatory response to $\mathrm{CO}_{2}$, baseline ventilation was determined while mice breathed $100 \% \mathrm{O}_{2}$ followed by hypercapnic challenge with $5 \% \mathrm{CO}_{2}-95 \% \mathrm{O}_{2}$-balance $\mathrm{N}_{2}$. Sighs, sniffs, and movement-induced changes in breathing were monitored and excluded in the analysis. All recordings were made at an ambient temperature of $25 \pm 1{ }^{\circ} \mathrm{C}$. Minute ventilation $\left(\mathrm{V}_{E}=\right.$ Tidal volume, $\mathrm{V}_{\mathrm{T}} \mathrm{x}$ respiratory rate, $\mathrm{RR}$ ) was calculated and normalized for body weight and expressed as ratio to $\mathrm{O}_{2}$ consumption $\left(\mathrm{V}_{E} / \mathrm{VO}_{2}\right)$.

Measurements of efferent phrenic nerve activity- Mice were anaesthetized with intraperitoneal injections of urethane $(1.2 \mathrm{~g} / \mathrm{kg})$. Supplemental doses $(10 \%$ of the initial dose of anesthetic) were given when corneal reflexes or responses to toe pinch were observed. Animals were placed on a warm surgical board and a tracheotomy was performed through a midline neck incision. The 
trachea was cannulated and mice were allowed to breathe spontaneously. Core body temperature was monitored by a rectal thermistor probe and maintained at $37 \pm 1^{\circ} \mathrm{C}$ by a heating pad. The phrenic nerve was isolated unilaterally at the level of the C3 and C4 spinal segments, cut distally, and placed on bipolar stainless steel electrodes. Integrated efferent phrenic nerve activity was monitored as an index of central respiratory neuronal output. The electrical activity was filtered (band pass 0.3-1.0 kHz), amplified (P511K, Grass Instrument, West Warwick, RI), and passed through Paynter filters (time constant of $100 \mathrm{~ms}$; CWE Inc.) to obtain a moving average signal. Data were collected and stored in the computer for further analysis (PowerLab/8P, AD Instruments Pty Ltd, Australia). Phrenic nerve bursts/ min (index of respiratory rate, RR, tidal phrenic nerve activity, and minute neuronal respiration $(\mathrm{MNR}=\mathrm{RR} \times$ tidal phrenic nerve activity) were analyzed. The effects of hypoxia $\left(12 \% \mathrm{O}_{2}\right.$ balanced nitrogen) and hypercapnia $\left(5 \% \mathrm{CO}_{2}\right.$ balanced $95 \% \mathrm{O}_{2}$ ) on efferent phrenic nerve activity were determined. Gases were administered through a needle placed in the tracheal cannula and gas flow was controlled by a flow meter. For hypoxic response, baseline phrenic nerve activity was monitored while the animals breathed room air for 3 min. Subsequently, inspired gas was switched to $12 \% \mathrm{O}_{2}$ for 3min. The duration of $3 \mathrm{~min}$ for hypoxia was chosen because longer duration of hypoxic exposure (> 5min) in anesthetized mice leads to hypotension which confounds interpretation of results. For hypercapnic response, 3 min of $5 \% \mathrm{CO}_{2}$ balanced $95 \% \mathrm{O}_{2}$ was preceded by exposure to $100 \% \mathrm{O}_{2}$ for $3 \mathrm{~min}$. At the end of the experiment, mice were killed by overdose of urethane $(>3.6 \mathrm{~g} / \mathrm{kg}$, i.p.).

\section{Hyperoxic Challenge (Dejours test)}

These experiments were performed on anesthetized mice. Baseline neural respiration (efferent phrenic nerve activity) was recorded while animals breathed $21 \% \mathrm{O}_{2}$ for $45 \mathrm{sec}$ followed by 
$100 \% \mathrm{O}_{2}$ for $20 \mathrm{sec}$. Respiratory variables were analyzed during $21 \% \mathrm{O}_{2}$ breathing and during the last $15 \mathrm{sec}$ of hyperoxia (the initial $5 \mathrm{sec}$ was excluded because of the dead space).

\section{Recording of CB sensory nerve activity}

Sensory nerve activity from CB ex vivo was recorded as previously described (Peng et al. 2006). Briefly, CBs along with the sinus nerves were harvested from anaesthetized mice, placed in a recording chamber (volume, $250 \mu \mathrm{l})$ and superfused with warm physiological saline $\left(35^{\circ} \mathrm{C}\right)$ at a rate of $3 \mathrm{ml} /$ minute. The composition of the medium was (mM): $\mathrm{NaCl}, 125 ; \mathrm{KCl}, 5 ; \mathrm{CaCl}_{2}, 1.8$; $\mathrm{MgSO}_{4}, 2 ; \mathrm{NaH}_{2} \mathrm{PO}_{4}, 1.2 ; \mathrm{NaHCO}_{3}, 25 ; \mathrm{D}-$ Glucose, 10; Sucrose, 5. The solution was bubbled with $21 \% \quad \mathrm{O}_{2} / 5 \% \quad \mathrm{CO}_{2}$. Hypoxic/hypercapnic challenges were achieved by switching the perfusate to physiological saline equilibrated with desired levels of $\mathrm{O}_{2}$. To facilitate recording of clearly identifiable action potentials, the sinus nerve was treated with $0.1 \%$ collagenase for 5 min. Action potentials (1-3 active units) were recorded from one of the nerve bundles with a suction electrode and stored in a computer via a data acquisition system (PowerLab/8P). 'Single' units were selected based on the height and duration of the individual action potentials using the spike discrimination module. Oxygen level of the superfusate medium in the chamber was continuously monitored with a platinum electrode placed next to the $\mathrm{CB}$ using a polarographic amplifier (Model 1900, A-M Systems, Sequim, WA).

\section{Primary cultures of glomus cells}

Primary cultures of glomus cells were prepared as described previously (Makarenko et al. 2012). Briefly, CBs were harvested from urethane (1.2 g/kg, I.P.) anesthetized mice. Glomus cells were dissociated using a mixture of collagenase P ( $2 \mathrm{mg} / \mathrm{ml}$; Roche, USA), DNase $(15 \mu \mathrm{g} / \mathrm{ml}$; Sigma, USA), and bovine serum albumin (BSA; $3 \mathrm{mg} / \mathrm{ml}$; Sigma, USA) at $37^{\circ} \mathrm{C}$ for $20 \mathrm{~min}$, followed by a 15 min incubation in medium containing DNase $(30 \mu \mathrm{g} / \mathrm{ml})$ only. Cells were plated on collagen 
(type VII; Sigma)-coated cover slips and maintained at $37^{\circ} \mathrm{C}$ in a $7 \% \mathrm{CO}_{2}+20 \% \mathrm{O}_{2}$ incubator for overnight $(\sim 18 \mathrm{~h})$. The growth medium consisted of F-12K medium (Invitrogen) supplemented with $1 \%$ fetal bovine serum, insulin-transferrin-selenium (ITS-X; Invitrogen), and $1 \%$ penicillin/streptomycin/glutamine mixture (Invitrogen).

\section{Measurements of $\left[\mathrm{Ca}^{2+}\right] \mathrm{i}$}

Glomus cells were incubated in Hanks Balanced Salt Solution (HBSS) with $2 \mu \mathrm{M}$ fura-2-AM and $1 \mathrm{mg} / \mathrm{ml}$ albumin for $30 \mathrm{~min}$ and then washed in a fura-2-free solution for $30 \mathrm{~min}$ at $37^{\circ} \mathrm{C}$. The cover slip was transferred to an experimental chamber for determining the changes in $\left[\mathrm{Ca}^{2+}\right]_{\mathrm{i}}$. Background fluorescence at 340nm and $380 \mathrm{~nm}$ wavelengths was obtained from an area of the cover slip that was devoid of cells. On each cover slip, glomus cells were identified by their characteristic clustering and individual cells were imaged. Image pairs (one at 340nm and the other at 380nm wavelength, respectively) were obtained every 2 s by averaging 16 frames at each wavelength. Data were continuously collected throughout the experiment. Background fluorescence was subtracted from the cell data obtained at the individual wavelengths. The image obtained at $340 \mathrm{~nm}$ was divided by the $380 \mathrm{~nm}$ image to obtain ratiometric image. Ratios were converted to free $\left[\mathrm{Ca}^{2+}\right]_{\mathrm{i}}$ using calibration curves constructed in vitro by adding fura-2 $(50 \mu \mathrm{M}$ free acid) to solutions containing known concentrations of $\mathrm{Ca}^{2+}(0-2000 \mathrm{nM})$. The recording chamber was continually superfused with warm solution $\left(31^{\circ} \mathrm{C}\right)$ from gravity-fed reservoirs. The composition of the medium was the same as that employed for recording CB sensory activity described above.

\section{Data analysis}

The following variables were analyzed in un-anaesthetized mice: tidal volume (VT; $\mu \mathrm{l}$ ); respiratory rate $(\mathrm{RR} / \mathrm{min})$; minute ventilation $\left(\mathrm{V}_{E} ; \mathrm{ml} / \mathrm{min} \cdot \mathrm{g}\right.$ body weight $) ; \mathrm{O}_{2}$ consumption $\left(\mathrm{V}_{O 2}\right.$; $\mathrm{ml} / \mathrm{min}) ; \mathrm{CO}_{2}$ production $\left(\mathrm{VCO}_{2} ; \mathrm{ml} / \mathrm{min}\right)$. In agreement with other investigators (Tankersley, 
Fitzgerald and Kleeberger 1994, Dauger et al. 1998, Tankersley et al. 1993), we also found that breathing is unstable in un-sedated mice due to movement, sniffing and exploratory behaviors. Therefore, 15-20 consecutive stable breaths per minute were chosen for analysis of respiratory variables during breathing room air and during 5 min of inspired $\mathrm{O}_{2}$ and $\mathrm{CO}_{2}$ challenges. $\mathrm{V}_{T}$ and $\mathrm{V}_{E}$ were normalized to the body weight of the animals. Each data point represents the average of two trials in a given animal for a given gas challenge. In anaesthetized animals, the following respiratory variables were analyzed: respiratory rate (RR; phrenic bursts per minute), amplitude of the integrated tidal phrenic nerve activity (a.u., arbitrary units) and minute neural respiration $(\mathrm{MNR})$ (number of phrenic bursts per min, $\mathrm{RR} \times$ amplitude of the integrated tidal phrenic nerve activity, a.u.). CB sensory activity (discharge from 'single' units) was averaged during 3 min of baseline and during the $3 \mathrm{~min}$ of gas challenge and expressed as impulses per second unless otherwise stated. All data are presented as Box-Whisker plots with individual data points, unless otherwise stated. Statistical significance was assessed by either Mann-Whitney Rank Sum test or two-way ANOVA with repeated measures followed by Tukey's test. $\mathrm{P}$ values $<0.05$ were considered significant. 


\section{RESULTS}

Impaired hypoxic ventilatory response (HVR) in Olfr 78 null mice

In the first series of experiments, breathing was monitored by plethysmography in unsedated mice. Examples of the hypoxic ventilatory response (HVR) and summary data of $\mathrm{V}_{\mathrm{E}} / \mathrm{VO}_{2}$ in both WT and Olfr78 null mice (on BL6 and JAX backgrounds) as percentage of normoxia is presented in Fig. 1 A-D. Absolute values of respiratory changes and metabolic variables $\left(\dot{V}_{\mathrm{O}_{2}}, \dot{V}_{\mathrm{CO}_{2}}, \dot{V}_{\mathrm{E}} / \dot{V}_{\mathrm{O}_{2}},\right)$ are given in Table $1 \mathrm{~A}$ and $\mathrm{B}$. Baseline breathing $\left(21 \% \mathrm{O}_{2}\right)$ was comparable between WT and Olfr78 null mice (BL6 and JAX background strains). Minute ventilation presented as $\mathrm{V}_{E} / \mathrm{V}_{O 2}$, a measure of convective requirement, increased in response to $12 \% \mathrm{O}_{2}$ in WT mice, which was primarily due to increased respiratory rate (Fig.1 A-D; Table 1 a-b). The magnitude of HVR was significantly attenuated in Olfr78 null mice on both BL6 and JAX backgrounds (Fig.1 A-D; Table $1 \mathrm{a}-\mathrm{b})$.

In the second series of experiments, efferent phrenic nerve activity was monitored as an index of respiratory neuronal output in anesthetized mice. Examples of neural breathing responses to hypoxia $\left(12 \% \mathrm{O}_{2}\right)$ in WT and Olfr78 null mice on BL6 and JAX background and summary data of minute neural respiration during hypoxia are presented in Figure 2 A-D. WT mice showed increased minute neural respiration during hypoxia, which was due to increased phrenic burst frequency $(\mathrm{RR})$ as well as tidal phrenic amplitude and these responses were markedly attenuated in Olfr78 null mice (Fig.2 A-D).

In contrast, WT and Olfr78 null mice (BL6 and JAX background) responded to hypercapnia $\left(5 \% \quad \mathrm{CO}_{2}\right)$ with comparable increases in breathing measured either by plethysmography (Fig. 3 A-D) or by efferent phrenic nerve activity (Fig. 4 A-D). 


\section{Assessment of carotid body function in Olfr 78 null mice}

The magnitude of the transient depression of breathing in response to a brief hyperoxic exposure is considered as an index of peripheral chemoreceptor, especially the CB sensitivity to $\mathrm{O}_{2}$ (Dejours 1962). Phrenic nerve activity was monitored in anesthetized mice for $45 \mathrm{sec}$ while breathing room air and then for $20 \mathrm{sec}$ after a hyperoxic challenge $\left(100 \% \mathrm{O}_{2}\right)$. As compared with Olfr78 null mice (BL6 and JAX backgrounds), wild-type mice manifested a significantly greater depression of minute neural respiration in response to hyperoxia (Fig. 5 A-D).

To further establish the effects of hypoxia, CBs were isolated from mutant mice on both BL6 and JAX backgrounds as well as corresponding wild-type mice, and the carotid sinus nerve activity was recorded ex vivo. CBs were challenged with graded hypoxia. Examples illustrating the effect of hypoxia $\left(\mathrm{pO}_{2} \sim 40 \mathrm{mmHg}\right.$ ) in Olfr 78 (BL6 and JAX backgrounds) and the corresponding wild-type mice are shown in Fig. 6 A-B and average data of CB sensory responses to graded hypoxia are presented in Fig. 6 C-D. The magnitude of sensory nerve response at given $p \mathrm{O}_{2}$ was significantly less in Olfr78 null CBs on both BL6 and JAX backgrounds as compared to corresponding wild-type CBs (Fig. 6 C-D).

\section{$\left[\mathrm{Ca}^{2+}\right]_{i}$ responses of glomus cells to hypoxia}

We next determined whether Olfr78 is required for $\left[\mathrm{Ca}^{2+}\right]_{i}$ response of glomus cells to hypoxia. Studies were conducted on glomus cells isolated from wild type and Olfr78 mutant mice on BL6 and JAX backgrounds, and were maintained overnight $(\sim 18 \mathrm{~h})$ in a growth medium. For these experiments, we chose $p \mathrm{O}_{2} \sim 30 \mathrm{mmHg}$ because severe hypoxia $\left(p \mathrm{O}_{2}<30\right.$ $\mathrm{mmHg}$ ) produces markedly reduced sensory nerve excitation(Peng et al. 2019).

Hypoxia increased $\left[\mathrm{Ca}^{2+}\right]_{\mathrm{i}}$ in wild-type glomus cells and this effect was attenuated in Olfr78 mutant mice raised either on BL6 or JAX background (Fig. 7A-D). In contrast, $\left[\mathrm{Ca}^{2+}\right]_{\mathrm{i}}$ 

not certified by peer review) is the author/funder. All rights reserved. No reuse allowed without permission.

elevation produced by $40 \mathrm{mM} \mathrm{KCl}$, a non-selective depolarizing stimulus were comparable between wild-type and Olfr78 null glomus cells (Fig. 7 A-D). 


\section{DISCUSSION}

Consistent with the findings of Chang et al (Chang et al. 2015), we also found attenuated HVR, a hallmark of the CB chemo reflex, in un-sedated Olfr78 null mice as measured by whole body plethysmography. The reduced HVR was primarily due to attenuated respiratory rate rather than tidal volume and is reflected in minute ventilation which was normalized to body weight as well as oxygen consumption $\left(\mathrm{VO}_{2}\right)$, the later a measure of convective requirement. Such an attenuated HVR was evident in Olfr78 null mice both on BL6 and JAX background strains (Table 1), thereby negating any potential confounding influence of background strains. These observations differ from those reported by (Torres-Torrelo et al. 2018), who monitored integrated respiratory rate as a measure of breathing in un-sedated mice. However, we found it is technically not possible to integrate respiratory rate in un-sedated mice, because of highly unstable breathing arising from sniffing and exploratory behavior, which was also reported by other investigators (Tankersley et al. 1994, Dauger et al. 1998, Tankersley et al. 1993). Because of the unstable breathing, it was necessary to choose segments of 15-20 consecutive breaths of stable breathing every minute for analyzing breathing during baseline and during hypoxia in unsedated mice.

One might argue that our analysis of HVR is biased because of the choice of stable breaths. To circumvent this limitation, we further analyzed HVR by monitoring efferent phrenic nerve activity as an index of breathing in anesthetized mice. Our results showed a clear attenuation of HVR in anesthetized Olfr 78 null as compared to wild-type mice. Attenuated HVR in anesthetized Olfr 78 null mice is due to both reduced tidal volume as well as the respiratory rate as opposed to attenuated respiratory rate in un-sedated mice. Remarkably, stimulation of breathing by $\mathrm{CO}_{2}$ was unaffected in Olfr78 null mice measured either by plethysmography or by 
efferent nerve activity. Taken together, these results demonstrate selective impairment of HVR, which is a hallmark of the CB chemo reflex, in mice lacking Olfr78.

It is well established that depression of breathing evoked by brief hyperoxia is an indirect measure of peripheral chemo receptor sensitivity to oxygen both in humans (Dejours 1962), and in experimental animals (Kline et al. 1998). Olfr 78 null mice (both on BL6 and JAX background) displayed remarkable attenuation of breathing depression by hyperoxia, suggesting impaired peripheral chemo receptor, possibly $\mathrm{CB}$ sensitivity to $\mathrm{O}_{2}$. To further establish the effects of Olfr78 deficiency on $\mathrm{CB}$ function, we directly monitored the $\mathrm{CB}$ sensory nerve responses to graded hypoxia. It is clear from our results, CB sensory nerve response to any given $p \mathrm{O}_{2}$ is markedly attenuated in Olfr78 generated both on BL6 or JAX backgrounds. Consistent with the response of the $\mathrm{CB}$ sensory nerve activity, hypoxia-evoked $\left[\mathrm{Ca}^{2+}\right]_{i}$ elevation of glomus cells is also impaired in Olfr78 null mice, whereas $\left[\mathrm{Ca}^{2+}\right]_{\mathrm{i}}$ elevation evoked by $\mathrm{KCl}$, a nonselective depolarizing stimulus was unaffected. These findings are consistent with the earlier observations by Chang et al. (Chang et al. 2015), and demonstrate that Olfr78 is an important component of the CB hypoxic sensing pathway.

In striking contrast to present observations, Torres-Torrelo et al found that hypoxiaevoked $\left[\mathrm{Ca}^{2+}\right]_{\mathrm{i}}$ elevation was unaffected in Olfr78 null glomus cells (Torres-Torrelo et al. 2018). A major difference between our study and by Torres-Torrelo et al (Torres-Torrelo et al. 2018) is the severity of hypoxia used for evoking $\left[\mathrm{Ca}^{2+}\right]_{i}$ elevation in glomus cells. Torres-Torrelo et al used 10-15 mmHg $\mathrm{pO}_{2}$ (Torres-Torrelo et al. 2018), whereas we employed $\mathrm{pO} 2$ of $~ 30 \mathrm{mmHg}$. We recently reported that severe hypoxia (i.e., below pO2 of $30 \mathrm{mmHg}$ ) although evokes $\left[\mathrm{Ca}^{2+}\right]_{\mathrm{i}}$ elevation in glomus cells but produces only a weak stimulation of the CB sensory nerve activity and depress breathing rather than stimulation (Peng et al. 2019). Therefore, we employed a 
medium $\mathrm{pO}_{2}$ of $\sim 30 \mathrm{mmHg}$ for eliciting $\left.\mathrm{Ca}^{2+}\right]_{\mathrm{I}}$ response of glomus cells, which produces robust CB sensory nerve excitation (Fig. 6), which is an essential pre-requisite for triggering reflex stimulation of breathing. It follows that Olfr78 play an important role in the $\mathrm{CB}$ excitation to a physiologically relevant hypoxia but not to near anoxic stimulus.

Acknowledgement: This work was supported by National Institutes of Health grants P01-HL44454. 


\section{FIGURE LEGENDS}

Fig. 1. Ventilatory responses to hypoxia in wild type (WT) and Olfr $78^{-1-}$ mice on BL6 and JAX backgrounds. Ventilation was measured in un-sedated mice by whole body plethysmography under normoxia $\left(21 \% \mathrm{O}_{2}\right)$ and hypoxia $\left(12 \% \mathrm{O}_{2}\right)$ along with $\mathrm{O}_{2}$ consumption ( $\mathrm{V}_{\mathrm{O} 2}$ ). Hypoxia was given for $5 \mathrm{~min}$. Representative tracings of breathing are shown in $\boldsymbol{A}$ and $\boldsymbol{B}$. Summary data of minute ventilation normalized to body weight and oxygen consumption $\left(\mathrm{V}_{\mathrm{E}} / \mathrm{V}_{\mathrm{O} 2}\right)$, later representing measure of convective requirement are shown as Box-Whisker plots with individual data points in $\boldsymbol{C}$ and $\boldsymbol{D}$. In panels $\boldsymbol{C}$ and $\boldsymbol{D}$, parenthesis represents number of mice in each group. WT vs Olfr78 null mice, Mann-Whitney Rank Sum test, * $\mathrm{P}<0.05$.

Fig.2. $\boldsymbol{A}$-B . Examples of efferent phrenic nerve activity during 21 and $12 \% \mathrm{O}_{2}$ (at arrow) in anesthetized, spontaneously breathing wild-type (WT) (Upper panels) and Olfr78 null mice (Lower panels) on BL6 and JAX backgrounds. Raw Phr., action potentials of the phrenic nerve activity. $\int$ Phr., integrated phrenic nerve activity (a.u. arbitrary units). $\boldsymbol{C}-\boldsymbol{D}$. Box-Whisker plots with individual data points showing data of minute neural respiration (number of phrenic bursts/min $\mathrm{x}$ tidal phrenic activity) presented as percent of baseline activity during $21 \% \mathrm{O}_{2}$ breathing. Parenthesis represents number of mice in each group. WT vs Olfr78 null mice, MannWhitney Rank Sum test, **, $\mathrm{P}<0.01$.

Fig.3. Ventilatory responses to hypercapnia $\left(5 \% \mathrm{CO}_{2}\right)$ in wild type (WT) and Olfr $78^{-/-}$mice on BL6 and JAX backgrounds. Ventilation was measured in un-sedated mice by whole body plethysmography under hyperoxia $\left(100 \% \mathrm{O}_{2}\right)$, and hypercapnia $\left(5 \% \mathrm{CO}_{2}+95 \% \mathrm{O}_{2}\right)$. Hypercapnia challenge was given for 5 min. Representative tracings of breathing are shown in $\boldsymbol{A}$ and $\boldsymbol{B}$. Summary data of minute ventilation $\left(\mathrm{V}_{\mathrm{E}}\right)$ normalized to body weight in response to hypercapnia are shown in $\boldsymbol{C}$ and $\boldsymbol{D}$ as Box-Whisker plots with individual data points. Parenthesis represents 
number of mice in each group. WT vs Olfr78 null mice, Two-way ANOVA with repeated measures followed by Tukey test, n.s. not significant, $\mathrm{P}>0.05$ as compared to WT.

Fig. 4. $\boldsymbol{A}$-B . Efferent phrenic nerve activity during $100 \% \mathrm{O}_{2}$ and $5 \% \mathrm{CO}_{2}+95 \% \mathrm{O}_{2}$ breathing (at arrow) in anesthetized, spontaneously breathing wild-type (WT) (Upper panels) and Olfr78 null mice (Lower panels) on BL6 and JAX backgrounds, respectively. Raw Phr., action potentials of the phrenic nerve activity. $\int$ Phr., integrated phrenic nerve activity (a.u. arbitrary units). $\boldsymbol{C}-\boldsymbol{D}$. Box-Whisker plots with individual data points showing data of minute neural respiration (number of phrenic bursta/min $\mathrm{x}$ amplitude of tidal phrenic activity in a.u.) presented as percent of baseline breathing during $100 \% \mathrm{O}_{2}$ breathing. Parenthesis represents number of mice in each group. WT vs Olfr78 null mice, Mann-Whitney Rank Sum test, n.s. not significant, P > 0.05.

Fig. 5. $\boldsymbol{A}$ - $\boldsymbol{B}$. Efferent phrenic nerve responses to brief (20 s) exposure to $100 \% \mathrm{O}_{2}$ (at arrow) in anesthetized, spontaneously breathing wild-type (WT) (Upper panels) and Olfr78 null mice on BL6 and JAX background (Lower panels). Raw Phr., action potentials of the phrenic nerve activity. Phr., integrated efferent phrenic nerve activity. $\boldsymbol{C}$ - $\boldsymbol{D}$. Box-Whisker plots with individual data points showing data of hyperoxia-induced reduction in minute neural respiration (number of phrenic bursts/min $\mathrm{x}$ amplitude of tidal phrenic nerve activity in arbitrary units) presented as percent of baseline breathing in room air. Number of mice are presented in parenthesis. Wild type (WT) vs Olfr78 null mice, Mann-Whitney Rank Sum test, **, $\mathrm{P}<0.01, * \mathrm{P}<0.05$.

Fig. 6. Carotid body (CB) sensory nerve response to hypoxia in wild type (WT) and Olfr78 null $\left(\right.$ Olfr78 ${ }^{-/-}$) mice on BL6 $(\boldsymbol{A})$ and JAX $(\boldsymbol{B})$ background. $p \mathrm{O}_{2}(\mathrm{mmHg})$ in the superfusion medium measured by an $\mathrm{O}_{2}$ electrode placed closed to the $\mathrm{CB}$ (top panels), raw action potentials (middle panels) and integrated action potential frequency impulses per second (bottom panels). C-D. Average data (mean $\pm \mathrm{SEM}$ ) of CB sensory responses to graded hypoxia presented as stimulus- 
evoked response minus baseline levels $(\Delta$ impulse/sec). Numbers in parenthesis represent the number of fibers and number of CBs. WT vs Olfr78 ${ }^{-/}$; Two-way ANOVA with repeated measures followed by Tukey test, $* * \mathrm{P}<0.01$.

Fig. 7. $\left[\mathrm{Ca}^{2+}\right]_{\mathrm{i}}$ responses of glomus cells from wild type and Olfr78 null mice on BL6 (A) and JAX $(\boldsymbol{B})$ backgrounds to hypoxia $(\mathrm{Hx})$ and $40 \mathrm{mM} \mathrm{KCl}\left(\mathrm{K}^{+}\right) \cdot p \mathrm{O}_{2}$ in $\mathrm{mmHg}$ represents partial pressure of $\mathrm{O}_{2}$ in the medium irrigating the glomus cells. $\boldsymbol{C}-\boldsymbol{D}$. Box-Whisker plots with individual data points showing data of $\left[\mathrm{Ca}^{2+}\right]_{\mathrm{i}}$ responses of glomus cells to hypoxia and $40 \mathrm{mM}$ $\mathrm{K}^{+}$presented as stimulus-evoked response minus baseline levels $\left(\Delta\left[\mathrm{Ca}^{2+}\right]_{\mathrm{i}}, \mathrm{nM}\right)$. Number of glomus cells is presented in the parenthesis. WT vs Olfr78 null glomus cells, Mann-Whitney Rank Sum test, $* * \mathrm{P}<0.01$, n.s. not significant, $\mathrm{P}>0.05$.

Table 1. Respiratory and metabolic variables in un-sedated wild-type and Olfr78 null mice on BL6 (a) and JAX (b) backgrounds. Respiration was monitored by whole body plethysmography. Numbers in parenthesis represent number of mice. RR, respiratory rate per min, $V_{T}$, tidal volume $(\mu \mathrm{l})$, minute ventilation, $\mathrm{V}_{\mathrm{E}}$, Oxygen consumption, $\mathrm{V}_{\mathrm{O} 2}, \mathrm{CO}_{2}$ production, WT vs Olfr78 Two-way ANOVA with repeated measures followed by Tukey test, $* \mathrm{p}<0.05$. 


\section{REFERENCES}

Chang, A. J., F. E. Ortega, J. Riegler, D. V. Madison \& M. A. Krasnow (2015) Oxygen regulation of breathing through an olfactory receptor activated by lactate. Nature, 527, 240-4.

Dauger, S., E. Nsegbe, G. Vardon, C. Gaultier \& J. Gallego (1998) The effects of restraint on ventilatory responses to hypercapnia and hypoxia in adult mice. Respir Physiol, 112, 215-25.

Dejours, P. (1962) Chemoreflexes in breathing. Physiol Rev, 42, 335-58.

Kline, D. D., T. Yang, P. L. Huang \& N. R. Prabhakar (1998) Altered respiratory responses to hypoxia in mutant mice deficient in neuronal nitric oxide synthase. J Physiol, 511 ( Pt 1), 273-87.

Kumar, P. \& N. R. Prabhakar (2012) Peripheral chemoreceptors: function and plasticity of the carotid body. Compr Physiol, 2, 141-219.

Makarenko, V. V., J. Nanduri, G. Raghuraman, A. P. Fox, M. M. Gadalla, G. K. Kumar, S. H. Snyder \& N. R. Prabhakar (2012) Endogenous H2S is required for hypoxic sensing by carotid body glomus cells. Am J Physiol Cell Physiol, 303, C916-23.

Maßberg, D. \& H. Hatt (2018) Human Olfactory Receptors: Novel Cellular Functions Outside of the Nose. Physiol Rev, 98, 1739-1763.

Peng, Y. J., V. V. Makarenko, A. Gridina, I. Chupikova, X. Zhang, G. K. Kumar, A. P. Fox \& N. R. Prabhakar (2019) $\mathrm{H}_{2} \mathrm{~S}$ mediates carotid body response to hypoxia but not anoxia. Respir Physiol Neurobiol, 259, 75-85.

Peng, Y. J., G. Yuan, D. Ramakrishnan, S. D. Sharma, M. Bosch-Marce, G. K. Kumar, G. L. Semenza \& N. R. Prabhakar (2006) Heterozygous HIF-1alpha deficiency impairs carotid body-mediated systemic responses and reactive oxygen species generation in mice exposed to intermittent hypoxia. J Physiol, 577, 705-16.

Prabhakar, N. R., Y. J. Peng \& J. Nanduri (2018) Recent advances in understanding the physiology of hypoxic sensing by the carotid body. F1000Res, 7 . 
Rakoczy, R. J. \& C. N. Wyatt (2017) Acute oxygen sensing by the carotid body: a rattlebag of molecular mechanisms. J Physiol.

Schild, D. \& D. Restrepo (1998) Transduction mechanisms in vertebrate olfactory receptor cells. Physiol Rev, 78, 429-66.

Tankersley, C. G., R. S. Fitzgerald \& S. R. Kleeberger (1994) Differential control of ventilation among inbred strains of mice. Am J Physiol, 267, R1371-7.

Tankersley, C. G., R. S. Fitzgerald, W. A. Mitzner \& S. R. Kleeberger (1993) Hypercapnic ventilatory responses in mice differentially susceptible to acute ozone exposure. J Appl Physiol (1985), 75, 2613-9.

Torres-Torrelo, H., P. Ortega-Sáenz, D. Macías, M. Omura, T. Zhou, H. Matsunami, R. S. Johnson, P. Mombaerts \& J. López-Barneo (2018) The role of Olfr78 in the breathing circuit of mice. Nature, 561, E33-E40.

Zhou, T., M. S. Chien, S. Kaleem \& H. Matsunami (2016) Single cell transcriptome analysis of mouse carotid body glomus cells. J Physiol, 594, 4225-51. 
Fig.1

A

WT(BL6)

Olfr78 $^{-/-}$(BL6)

$21 \% \mathrm{O}_{2}$

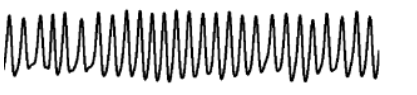

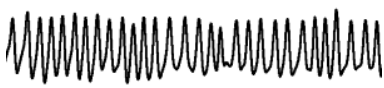
$\frac{\int_{1 \mathrm{~s}}}{100 \mu \mathrm{l}}$

$12 \% \mathrm{O}_{2}$
C
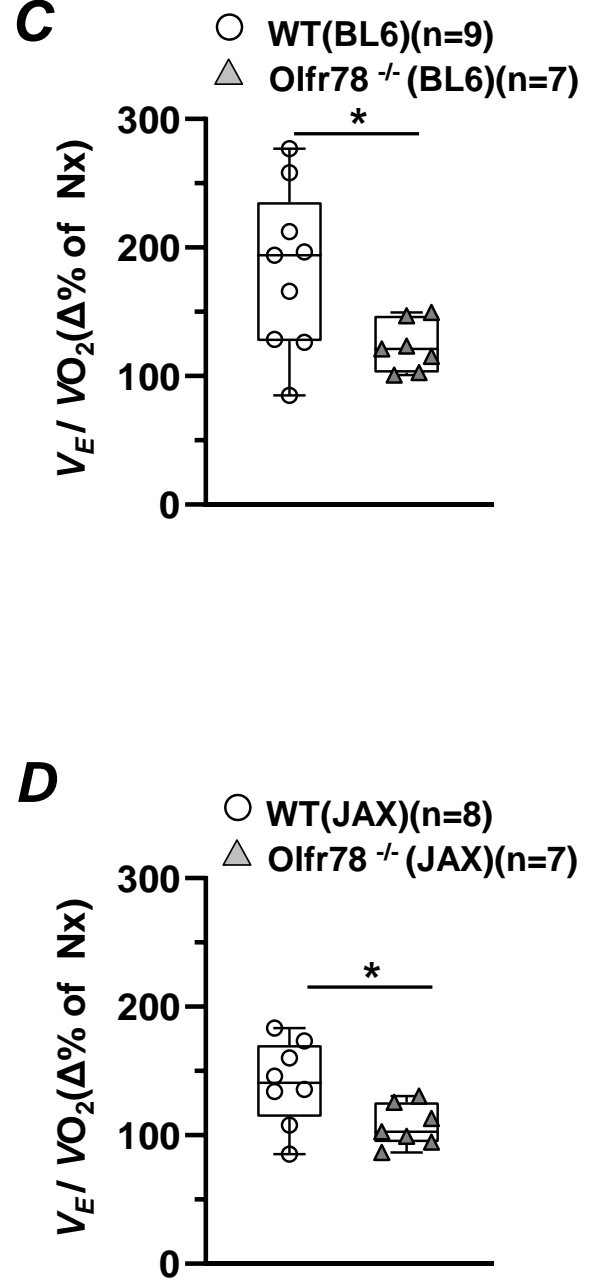
$\boldsymbol{A}$ WT(BL6)

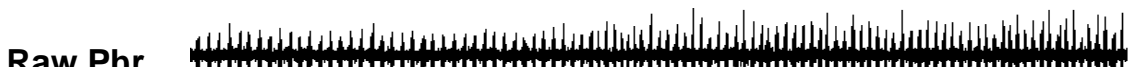

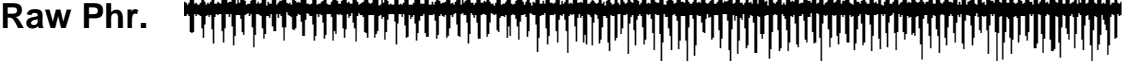

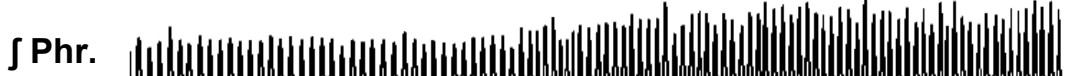
(a.u.)

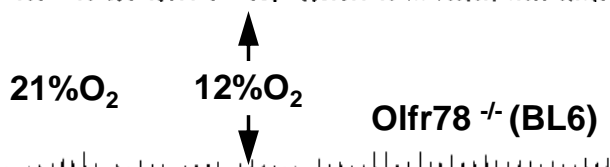

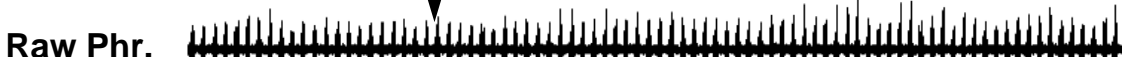

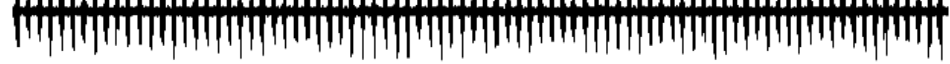

SPhr. Lutul|un

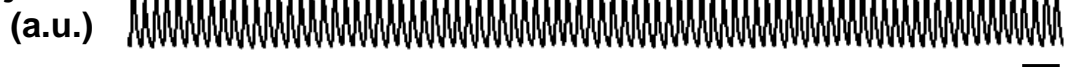

$\overline{1 s}$

\section{B}

WT(JAX)

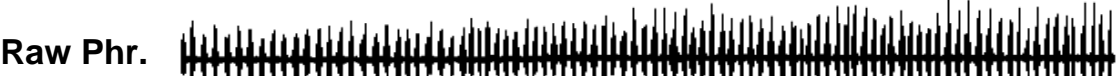

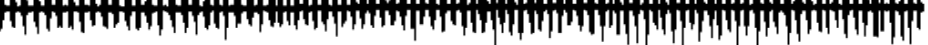

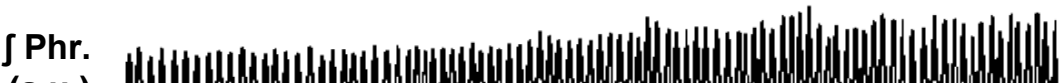

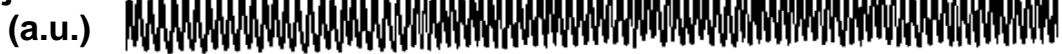

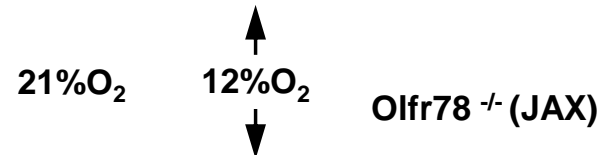

$\overline{1 s}$

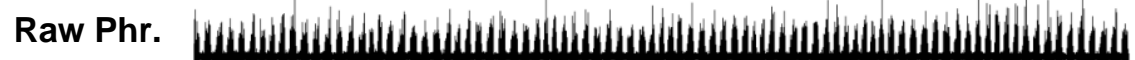

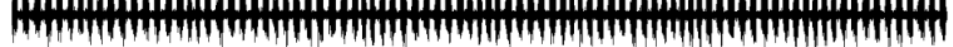

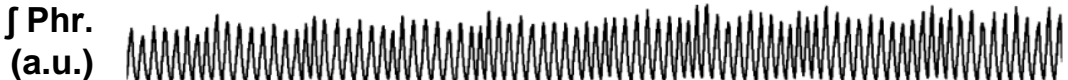

C

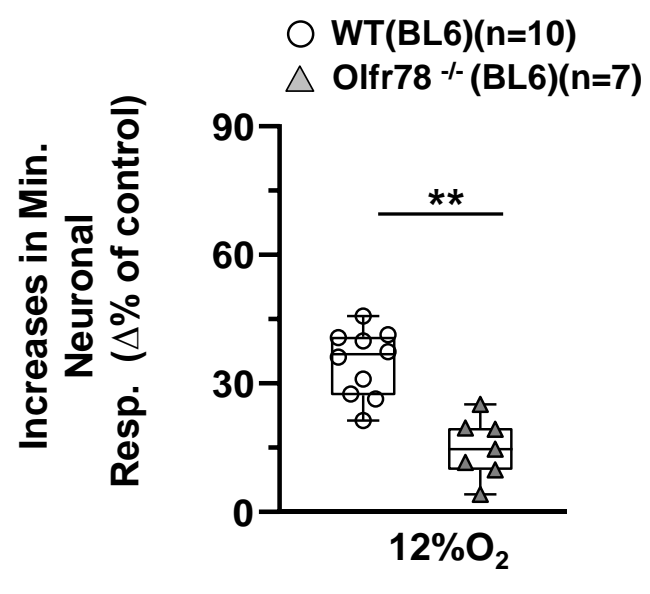

D

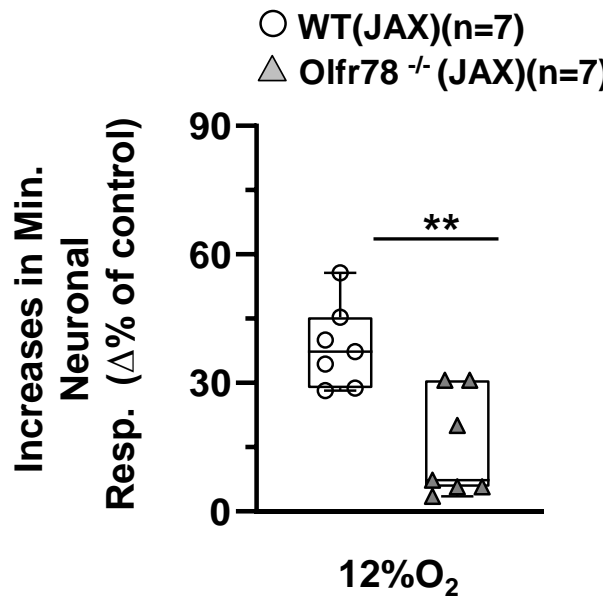


Fig.3

A

WT(BL6)

Olfr78 "/- (BL6)

$100 \% \mathrm{O}_{2}$

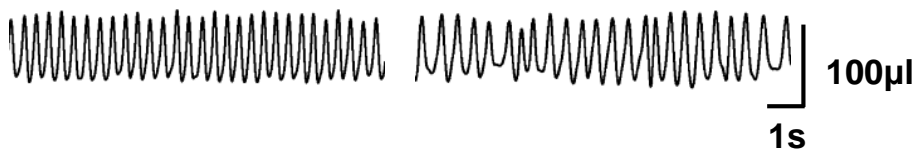

$5 \% \mathrm{CO}_{2}$

$+95 \% \mathrm{O}_{2}$
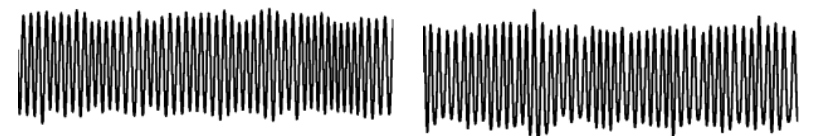

B

WT(JAX)

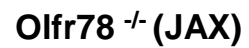

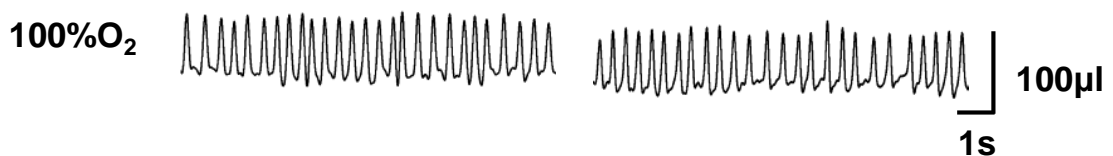

$5 \% \mathrm{CO}_{2}$ $+95 \% \mathrm{O}_{2}$
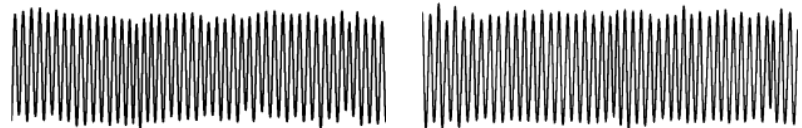

c

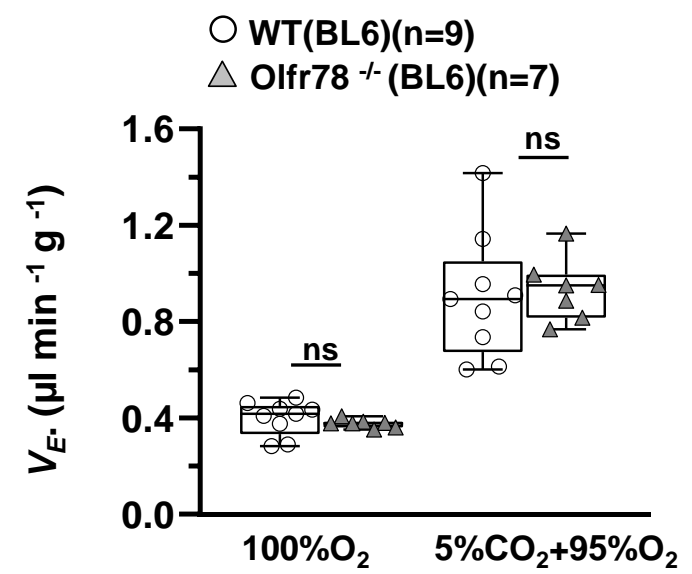

D

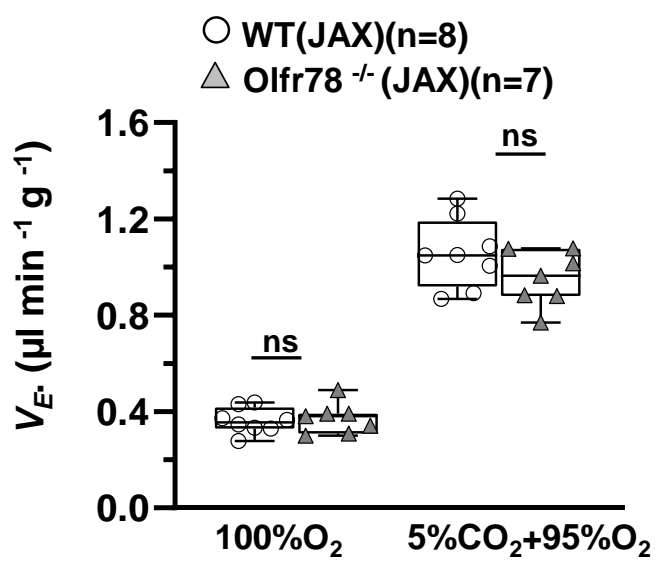


Raw Phr.

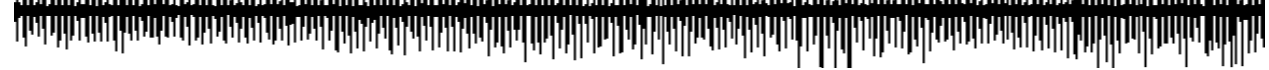
(a.u.)
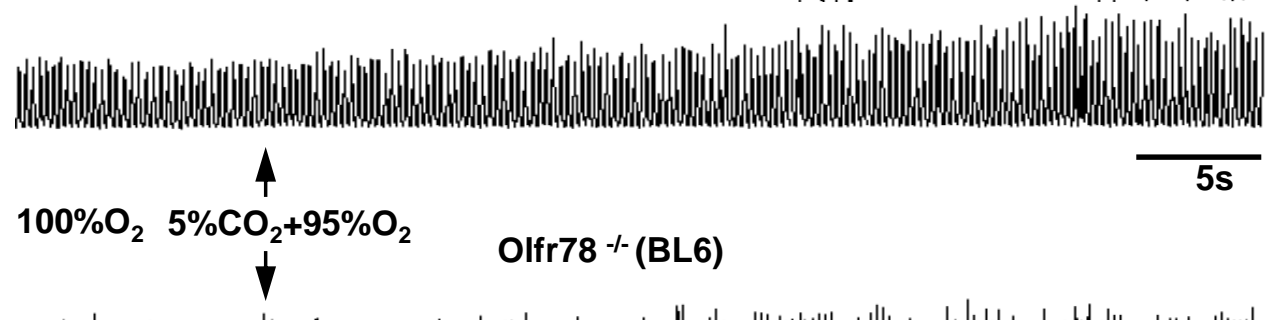

$$
\text { Olfr78 }{ }^{-/} \text {(BL6) }
$$

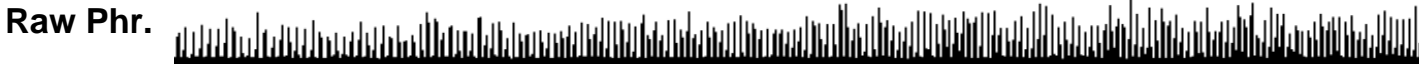

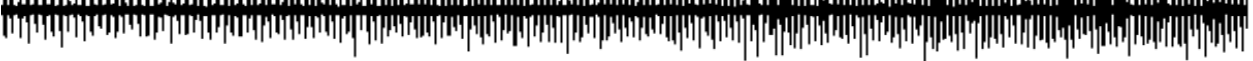

S Phr.

(a.u.)

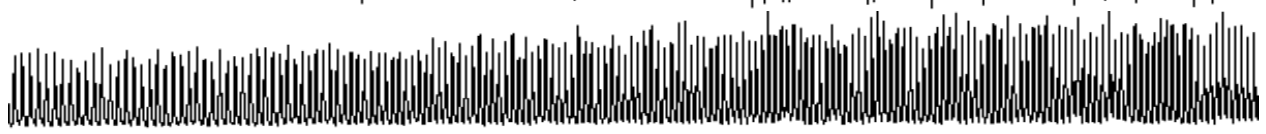

C

WT(JAX)

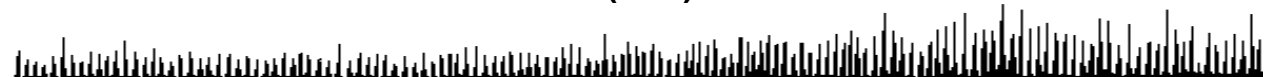

Raw Phr.

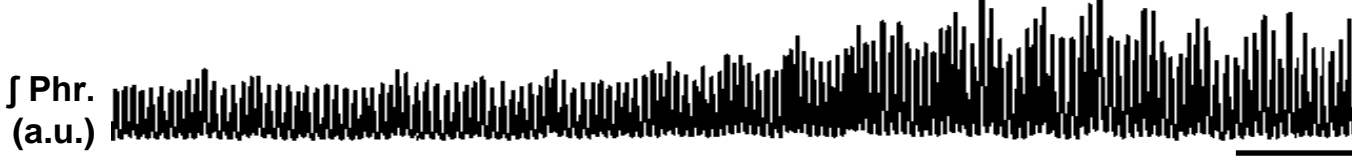

$$
100 \% \mathrm{O}_{2} \quad \mathrm{CO}_{2}+95 \% \mathrm{O}_{2}
$$$$
\text { Olfr78 }{ }^{-/} \text {(JAX) }
$$

Raw Phr.

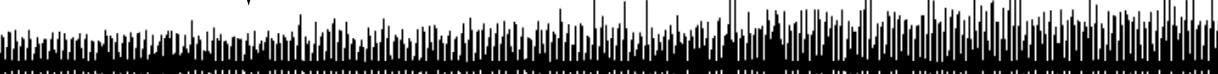

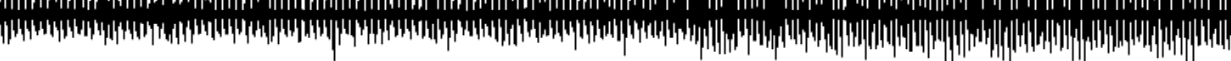

S Phr.

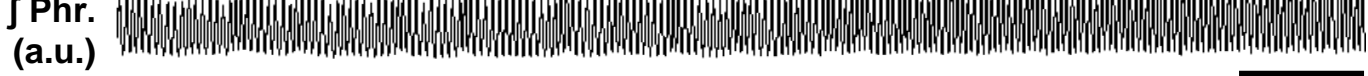

B

Fig.4

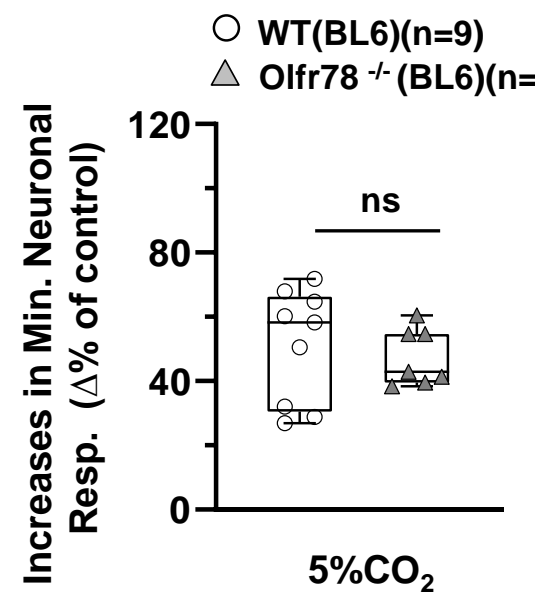

$\boldsymbol{D}$

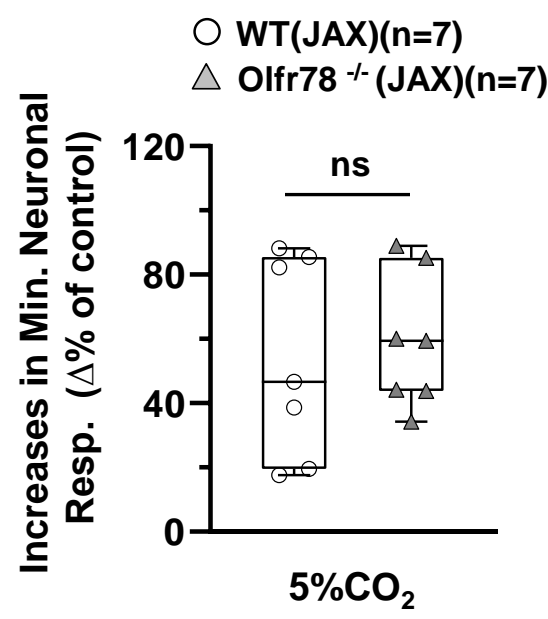




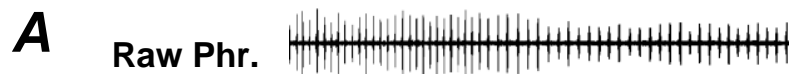

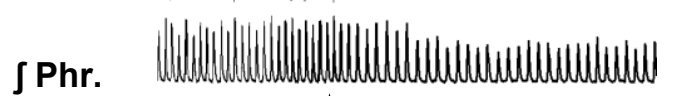
4
$100 \% \mathrm{O}_{2}$

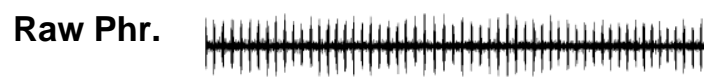

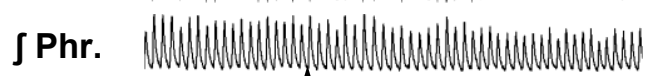
$100 \% \mathrm{O}_{2}$ Olfr78 $^{\text {/- }}$ (BL6) $\overline{1 s}$

B

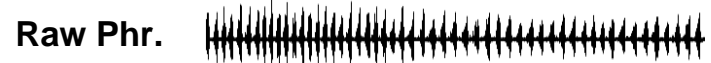

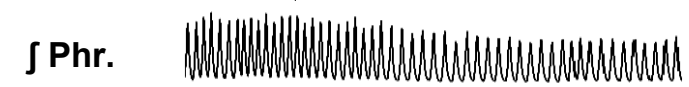
WT(JAX)

$$
\stackrel{4}{100 \% O_{2}}
$$

15

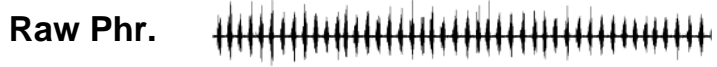

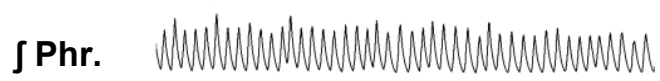

Olfr78 ${ }^{-/}(J A X)$

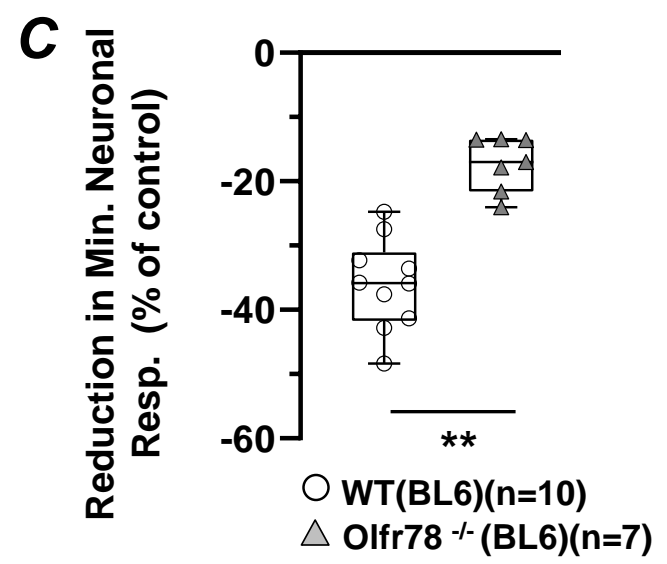

D

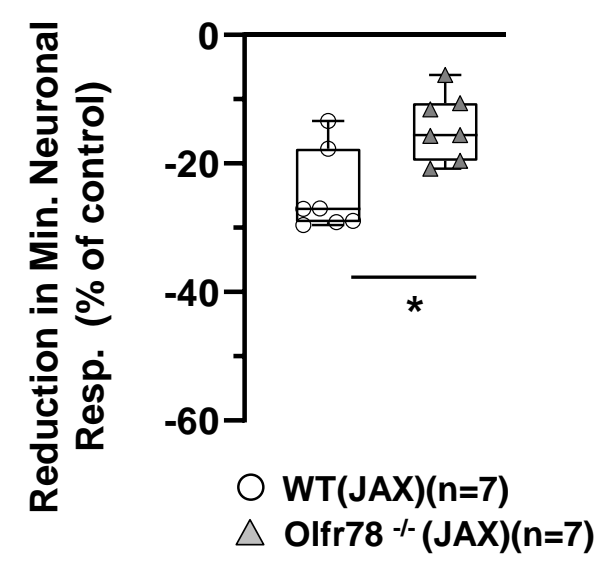



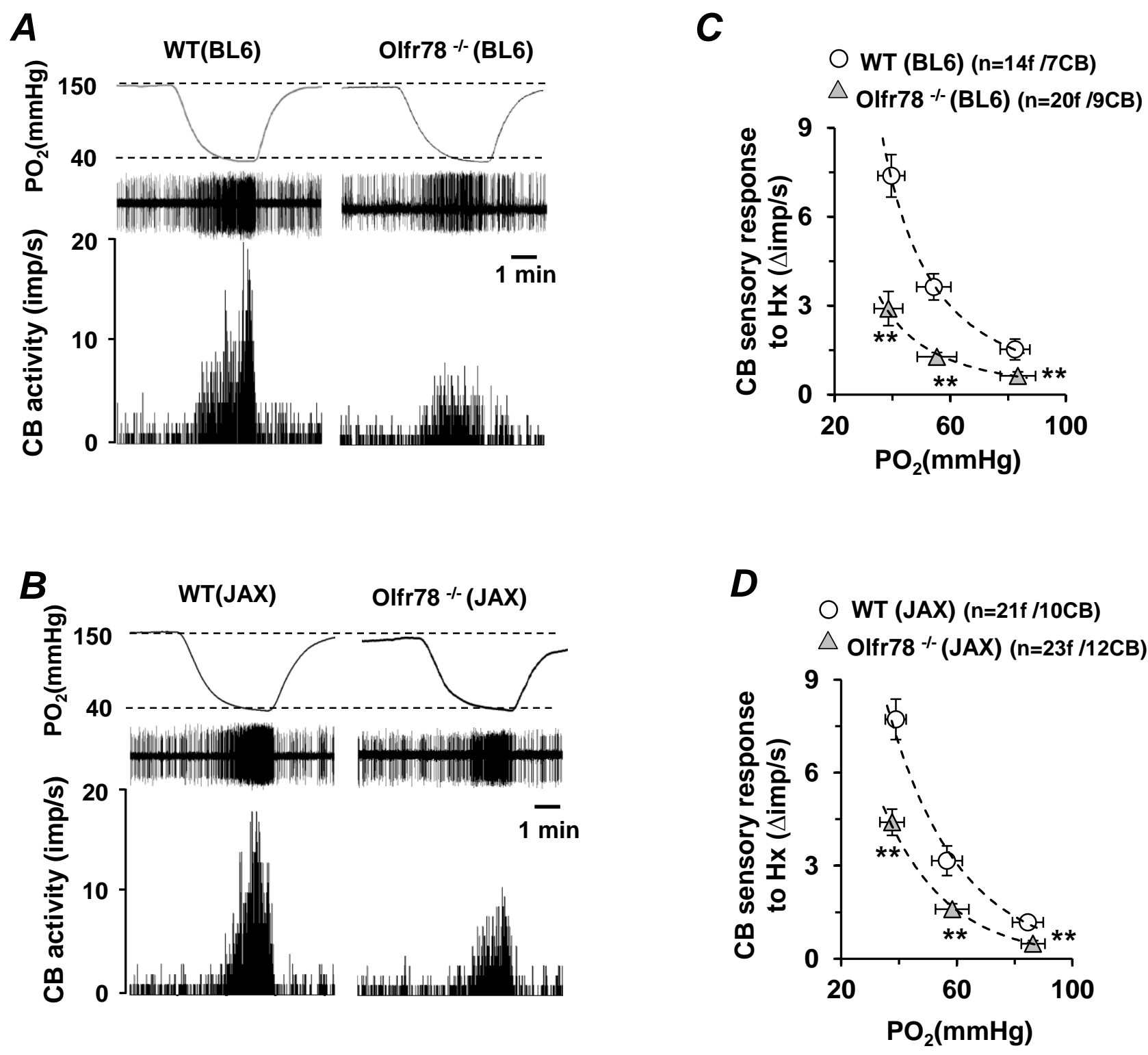
A

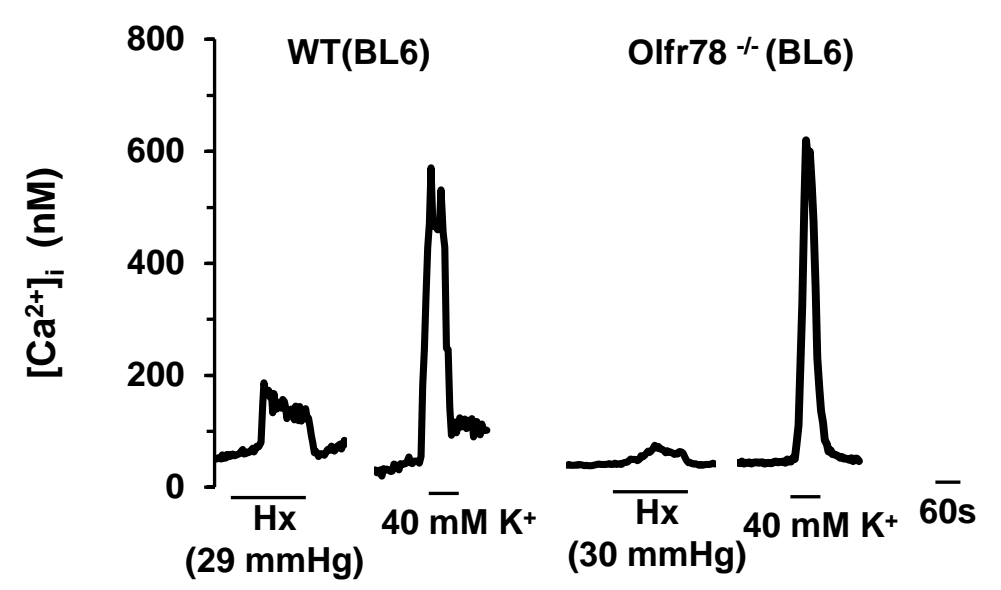

B

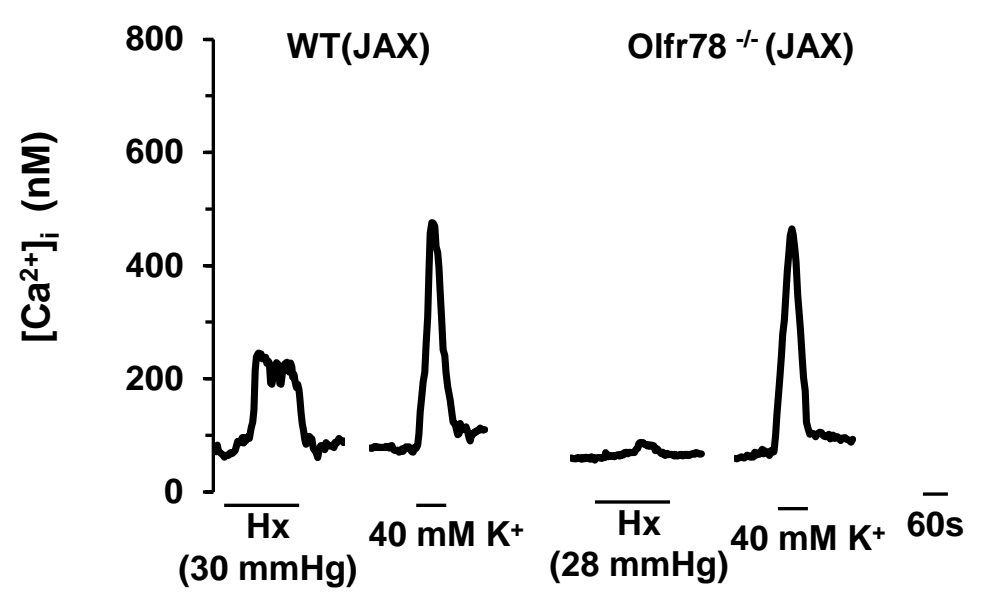

c

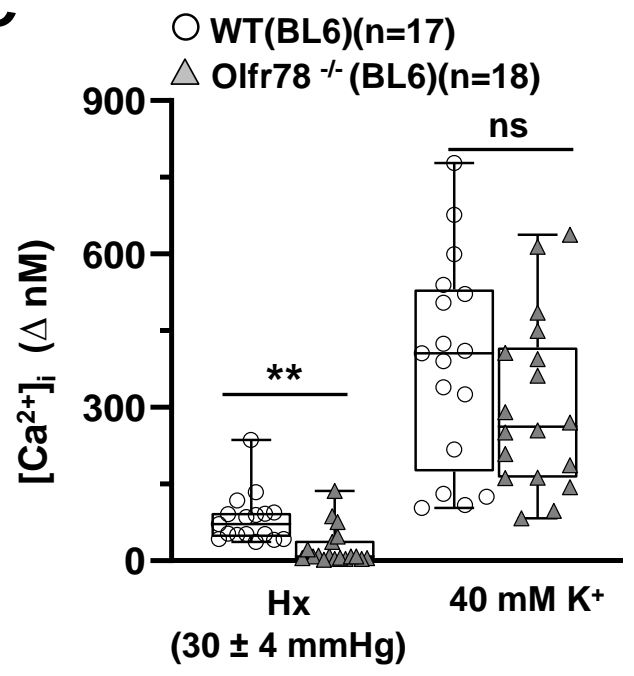

D

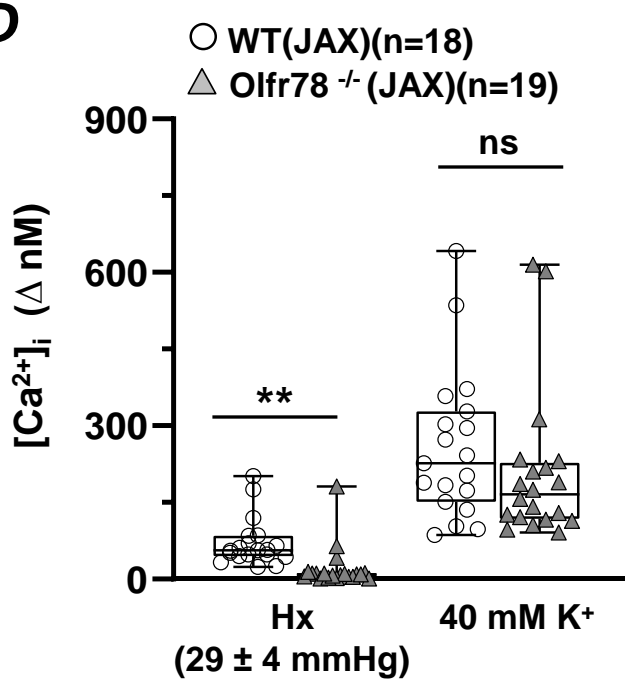


Table.1a

\begin{tabular}{|c|c|c|c|c|}
\hline \multirow{2}{*}{ BL6 background } & \multicolumn{2}{|c|}{ WT $(n=9)$} & \multicolumn{2}{|c|}{ Olfr78 $^{-/-}(n=7)$} \\
\hline & $21 \% \mathrm{O}_{2}$ & $12 \% \mathrm{O}_{2}$ & $21 \% \mathrm{O}_{2}$ & $12 \% \mathrm{O}_{2}$ \\
\hline RR (breaths/min) & $172 \pm 2$ & $230 \pm 3$ & $168 \pm 5$ & $201 \pm 4^{*}$ \\
\hline$V T(\mu \mathrm{l} / \mathrm{g})$ & $2.34 \pm 0.09$ & $2.68 \pm 0.06$ & $2.24 \pm 0.08$ & $2.58 \pm 0.08$ \\
\hline$V E(\mathrm{ml} / \mathrm{g} \cdot \mathrm{min})$ & $0.40 \pm 0.02$ & $0.61 \pm 0.01$ & $0.38 \pm 0.02$ & $0.52 \pm 0.01^{*}$ \\
\hline $\mathrm{VO}_{2}(\mathrm{ml} / \mathrm{g} \cdot \mathrm{min})$ & $0.051 \pm 0.003$ & $0.029 \pm 0.002$ & $0.053 \pm 0.002$ & $0.033 \pm 0.002$ \\
\hline $\mathrm{VCO}_{2}(\mathrm{ml} / \mathrm{g} \cdot \mathrm{min})$ & $0.040 \pm 0.002$ & $0.026 \pm 0.002$ & $0.039 \pm 0.004$ & $0.028 \pm 0.003$ \\
\hline $\mathrm{VE} / \mathrm{VO}_{2}$ & $8.01 \pm 0.43$ & $22.32 \pm 1.54$ & $7.17 \pm 0.31$ & $16 \pm 0.96^{*}$ \\
\hline
\end{tabular}

Table.1b

\begin{tabular}{|c|c|c|c|c|}
\hline \multirow[t]{2}{*}{ JAX background } & \multicolumn{2}{|c|}{ WT $(n=8)$} & \multicolumn{2}{|c|}{ Olfr78 $^{-/-}(n=7)$} \\
\hline & $21 \% \mathrm{O}_{2}$ & $12 \% \mathrm{O}_{2}$ & $21 \% \mathrm{O}_{2}$ & $12 \% \mathrm{O}_{2}$ \\
\hline RR (breaths/min) & $171 \pm 6.1$ & $237 \pm 13.8$ & $171 \pm 4.7$ & $206 \pm 5.7^{*}$ \\
\hline$V_{T}(\mu \mathrm{l} / \mathrm{g})$ & $2.35 \pm 0.06$ & $2.44 \pm 0.08$ & $2.42 \pm 0.11$ & $2.53 \pm 0.11$ \\
\hline$V_{E}(\mathrm{ml} / \mathrm{g} \cdot \mathrm{min})$ & $0.40 \pm 0.02$ & $0.58 \pm 0.04$ & $0.41 \pm 0.02$ & $0.52 \pm 0.02^{*}$ \\
\hline$V O_{2}(\mathrm{ml} / \mathrm{g} \cdot \mathrm{min})$ & $0.049 \pm 0.004$ & $0.030 \pm 0.002$ & $0.052 \pm 0.003$ & $0.032 \pm 0.002$ \\
\hline $\mathrm{VCO}_{2}(\mathrm{ml} / \mathrm{g} \cdot \mathrm{min})$ & $0.038 \pm 0.004$ & $0.026 \pm 0.002$ & $0.04 \pm 0.003$ & $0.025 \pm 0.002$ \\
\hline$V_{E} / V O_{2}$ & $8.3 \pm 0.6$ & $20.1 \pm 1.8$ & $8.0 \pm 0.4$ & $16.4 \pm 0.4^{*}$ \\
\hline
\end{tabular}

